\title{
SOLAR TRACKER CERDAS DAN MURAH BERBASIS MIKROKONTROLER 8 BIT ATMega8535
}

\author{
I Wayan Sutaya ${ }^{1}$, Ketut Udy Ariawan ${ }^{2}$ \\ 1,2Jurusan Teknik Elektronika, Universitas Pendidikan Ganesha \\ Singaraja, Indonesia \\ e-mail:wsutaya@undiksha.ac.id,udyariawan@undiksha.ac.id
}

\begin{abstract}
Abstrak
Penelitian ini telah menghasilkan prototipe produk solar tracker cerdas berbasis mikrokontroler AVR 8 bit. Solar tracker ini memasukkan filter digital IIR (Infinite Impulse Response) pada bagian program. Memprogram filter ini membutuhkan perkalian 32 bit sedangkan prosesor yang tersedia pada mikrokontroler yang dipakai adalah 8 bit. Proses perkalian ini hanya bisa dilakukan pada mikrokontroler 8 bit dengan menggunakan bahasa assembly yang merupakan bahasa level hardware. Solar tracker cerdas yang menggunakan mikrokontroler 8 bit sebagai otak utama pada penelitian ini menjadikan produk ini berbiaya rendah. Pengujian yang dilakukan menunjukkan bahwa solar tracker cerdas dibandingkan dengan solar tracker biasa mempunyai perbedaan konsumsi daya baterai yang sangat signifikan yaitu terjadi penghematan sebesar $85 \%$. Besar penghematan konsumsi daya ini tentunya bukan sebuah angka konstan melainkan tergantung seberapa besar noise yang dikenakan pada alat solar tracker. Untuk sebuah perlakuan yang sama, maka semakin besar noise semakin besar pula perbedaan penghematan konsumsi daya pada solar tracker yang cerdas.
\end{abstract}

Kata-kata kunci: solar tracker, filter digital, mikrokontroler 8 bit, konsumsi daya

\begin{abstract}
This research had made a prototype of smart solar tracker product based on microcontroller AVR 8 bit. The solar tracker used digital filter IIR (Infinite Impulse Response) on its software. Filter programming needs 32 bit multiplication but the processor inside of the microcontroller that used in this research is 8 bit. This multiplication is only can be solved on microcontroller 8 bit by using assembly language in programming. The language is a hardware level language. The smart solar tracker using the microcontroller 8 bit as a main brain in this research made the product had a low cost. The test results show that the comparison in saving of baterai power consumption between the smart solar tracker and the normal one is $85 \%$. The percentage of the saving indubitably is not a constant number but depend on how much noise occurs on the solar tracker. For the same operation of both kind of the solar tracker, the greater of noise will make the greater of the percentage of saving of power consumption for the smart solar tracker.
\end{abstract}

Keywords: solar tracker, digital filter, microcontroller 8 bit, power consumption 


\section{PENDAHULUAN}

Penelitian-penelitian yang terkait dengan perancangan dan pembuatan solar tracker cerdas telah dilakukan dengan tujuan agar solar tracker yang dihasilkan bisa menghemat konsumsi daya listrik. Sebagai contoh adalah penelitian yang dilakukan oleh V. Ramchandani dkk (2013) "Implementation of Maximum Power Point Tracking Using Kalman Filter for Solar Photovoltaic Array on FPGA" dan penelitian oleh M. A. Usta dkk (2011) "Design and Performance of Solar Tracking System with Fuzzy Logic Controller. Metode yang mereka gunakan adalah dengan memfilter sensor inputan sehingga mencegah gerakan yang tidak perlu. Metode yang kompleks ini diimplementasikan menggunakan perangkat prosesor digital yang mempunyai resource yang besar seperti DSP, FPGA, mikrokontroler 32 bit dan sebagainya sehingga biaya pembuatan alat solar tracker ini menjadi mahal. Hal ini tidak masalah apabila alat ini digunakan pada array sel surya, karena alat ini dijadikan sebagai pengendali untuk array sel surya yang bisa berukuran sebesar lapangan sepak bola. Tetapi di Indonesia alat solar tracker seperti ini sangat tidak cocok karena karena modul sel surya yang terpasang sebagain besar bahkan hapir seluruhnya berupa modul sel surya berskala kecil

Penelitian-penelitian lain yang terkait adalah membuat solar tracker menggunakan prosesor berkemampuan rendah seperti mikrokontroler 8 bit dengan tujuan alat solar tracker yang dihasilkan berbiaya murah. Penelitian ini telah dilakukan oleh S. Zubair dkk (2011), "Design and Construction of $A$ Microcontroller Based Single Axis Solar Tracker" dan oleh A. Mistry dkk(2014), "Design of An Automatic Solar Tracking System Based On Microcontroller". Tetapi penelitian-penelitian ini mengabaikan sistem cerdas pada alat solar tracker yang dibuat. Hal ini disebabkan ketidakmampuan peneliti untuk mengimplementasikan algoritma kendali yang kompleks pada prosesor berkemampuan rendah. Alat ini tidak akan bermanfaat apabila dipasang pada modul sel surya berskala kecil karena boros daya listrik dan hanya akan menghabiskan energi yang dihasilkan oleh modul sel surya.

Dari permasalahan yang telah diuraikan diatas, maka penelitian untuk membuat sebuah alat solar tracker yang cerdas dengan biaya yang murah sangat diperlukan di Indonesia. Adanya solar tracker yang cerdas dan murah akan mengatasi masalah dalam pemanfaatan energi surya saat ini dan merangsang pertumbuhan penggunaan energi surya di Indonesia.

Solar tracker yang cerdas dengan biaya yang murah bisa dibuat dengan mengimplementasikan algoritma kendali cerdas pada mikrokontroler 8 bit ATMega8535 yang berbiaya murah. Algoritma cerdas berupa filter digital yang berfungsi untuk mendeteksi noise dari sensor inputan. Filter digital ini mempunyai proses yang kompleks. Sehingga apabila diprogram, program yang dihasilkan akan mempunyai siklus waktu yang panjang.

Penelitian-penelitian seperti yang tersebut diatas gagal memprogram filter digital ini agar bisa dipasang pada mikrokontroler 8 bit yang berharga murah. Hal ini disebabkan oleh keterbatasan reseource mikrokontroler 8 bit. Penelitian tersebut tidak meneliti bagaimana siklus waktu yang panjang tersebut bisa diperpendek. Sehingga program yang dihasilkan hanya bisa dipasang pada mikrokontroler 32 bit yang mempunyai resource yang besar dan mahal.

Pada penelitian ini bahasa assembly akan digunakan untuk memprogram filter digital ini dibandingkan bahasa tingkat tinggi lainnya seperti $C$ dan Bascom karena dimungkinkan untuk memprogram pada level hardware sehingga siklus waktu bisa diperpendek dengan cara manipulasi register-register hardware. Dengan demikian filter digital yang diprogram ini bisa dipasang pada mikrokontroler 8 bit ATMega8535.

Sistem Solar Tracker ada beberapa jenis dan bisa diklasifikasikan berdasarkan beberapa criteria (Tudorache \& Kreindler, 2010). Klasifikasi pertama bisa dibuat berdasarkan pada jumlah sumbu putaran. Pada klasifikasi ini, solar tracker dibedakan menjadi dua yaitu: satu sumbu putaran dan dua sumbu putaran. Karena solar tracker 
mempunyai bagian penggerak dan sistem kontrol yang memerlukan biaya tinggi, maka solar tracker yang satu sumbu menjadi solusi terbaik untuk solar sel yang berukuran kecil. Solar Tracker yang satu sumbu biasanya mempunyai pengaturan sudut elevasi manual pada sumbu kedua yang diatur pada periode waktu yang tetap dalam setahun.

Sebuah sistem Solar Tracker satu sumbu menggunakan sebuah panel penyangga sel surya dan sebuah motor listrik untuk menggerakkan panel pada arah yang berhadapan dengan cahaya matahari seperti yang ditunjukkan pada Gambar 1 .

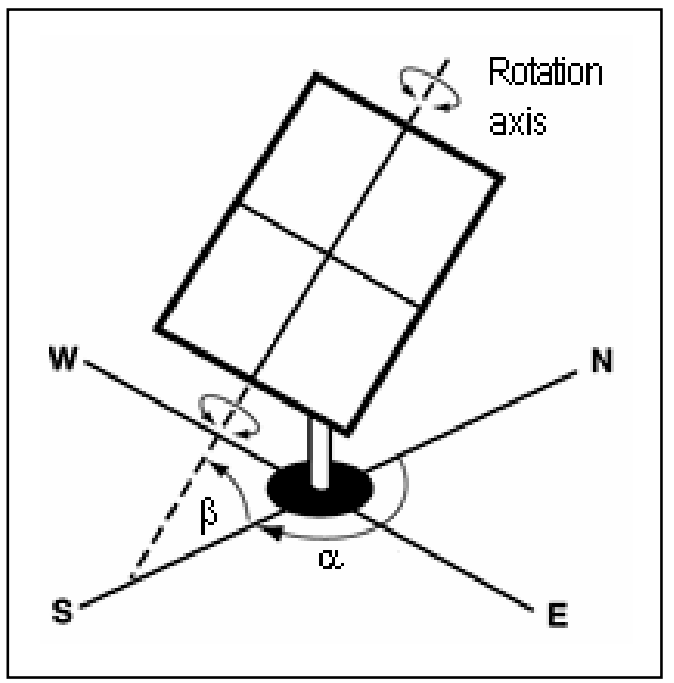

Gambar 1. Konsep sistem solar tracker satu sumbu (Tudorache \& Kreindler, 2010)

Klasifikasi yang lain dari sistem Solar Tracker bisa dibuat tergantung pada tipe orientasi. Berdasarkan orientasi ini, kita bisa mengidentifikasi sistem Solar Tracker menjadi dua yaitu: orientasi panel sel surya didasarkan pada lintasan matahari yang telah dihitung sebelumnya dan orientasi online yang bereaksi terhadap cahaya matahari secara langsung.

Sistem Solar Tracker satu sumbu mempunyai tiga tipe (Dhanabar. $R$ \& Bharathi. V. 2013) yaitu: Sistem Solar Tracker satu sumbu horizontal, Sistem Solar Tracker satu sumbu vertical dan sistem Solar Tracker satu sumbu miring. Pada sistem horizontal sumbu putaran adalah miring terhadap tanah, dan bagian muka dari modul dipasang paralel terhadap sumbu putaran. Pada sistem vertikal sumbu rotasi adalah vertikal terhadap tanah dan bagian muka modul dipasang pada sudut terhadap sumbu rotasi. Pada sistem miring sumbu rotasi adalah antara sumbu horizontal dan vertikal bagian muka dari modul juga dipasang paralel terhadap sumbu rotasi, seperti pada sistem horizontal. Sistem Solar Tracker satu sumbu terdiri dari dua LDR (Light Dependent Resistor) yang ditempatkan pada salah satu sisi panel. Tergantung pada intensitas sinar matahari salah satu dari dua LDR akan dibayangi dan satunya lagi akan tersinari. LDR dengan maksimum intensitas sinar matahari mengirim sinyal yang lebih kuat ke pengendali yang selanjutnya mengirim sinyal ke motor untuk memutar panel pada arah dimana intensitas matahari maksimum.
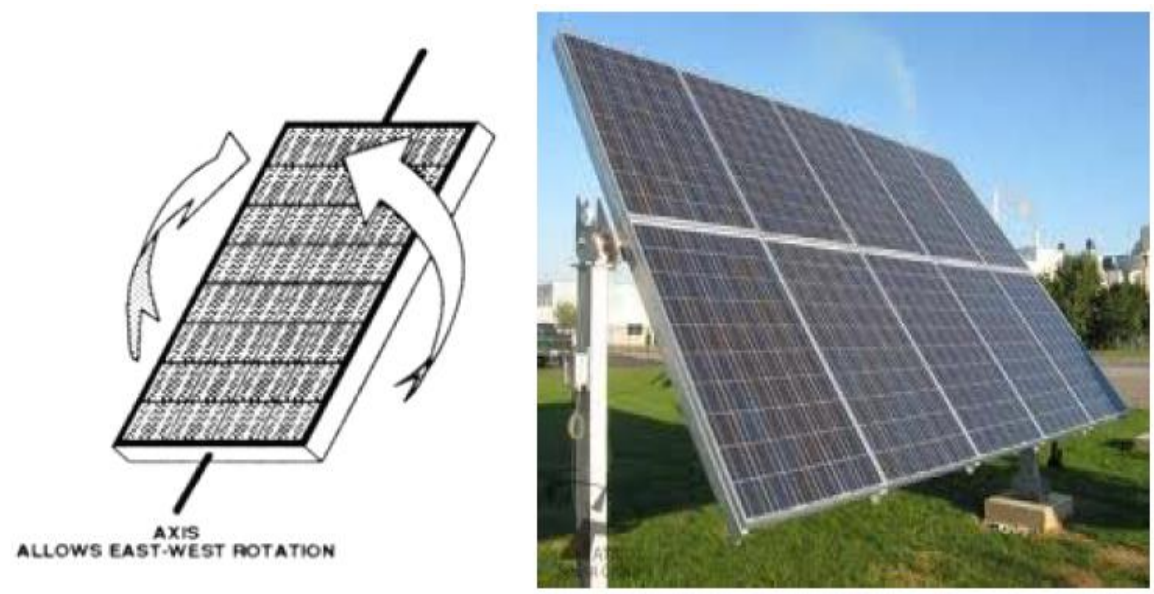

Gambar 2. Sistem solar tracker satu sumbu berdasarkan orientasi (Dhanabar, 2013) 
Disini sensor untuk mendeteksi arah dari cahaya matahari dengan menggunakan sel surya itu sendiri. Tegangan VPV dan arus output IPV dari sel surya dimasukkan ke pengolah digital (disini digunakan chip PSoC) dimana sebelumnya dilakukan penguatan untuk mencapai level sinyal input. Selanjutnya sinyal-sinyal ini disample oleh dua
ADC(Analog Digital Converter) 12 bit yang terpisah menjadi untaian digital. Selanjutnya digunakan filter digital IIR untuk menfilter noise frekeunsi tinggi, sehingga didapatkan sinyal asli dari VVP dan IVP. Sinyal ini kemudian diolah dengan metode algoritma perturbation adaptive, kemudian mengirimkan duty cycle ke PWM 16 bit untuk menggerakkan motor DC.

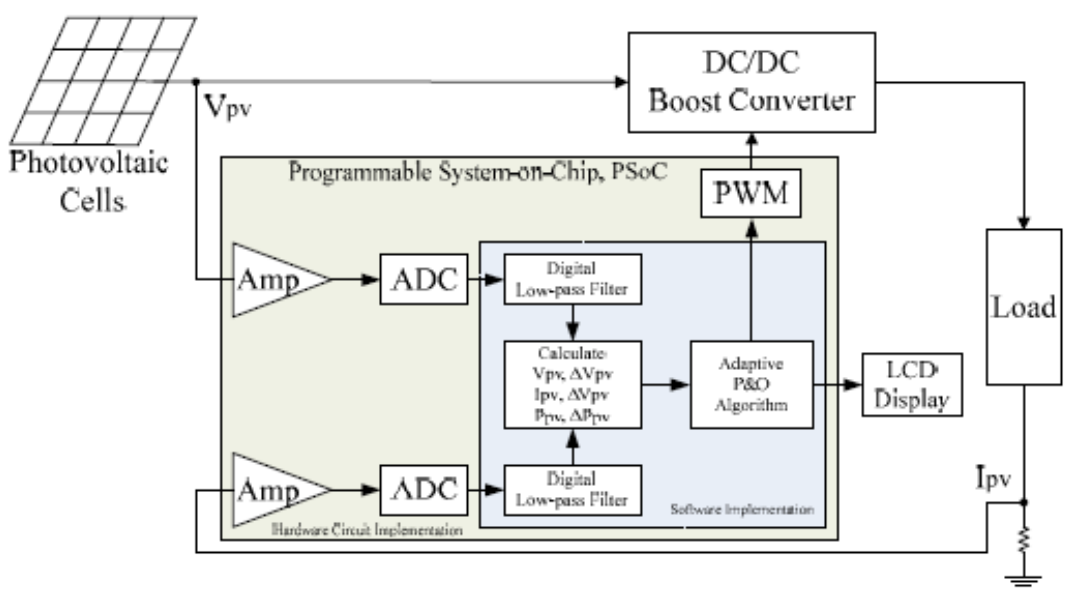

Gambar 3. Susunan model sistem solar tracker satu sumbu (W. Jwo, 2010)

Pada sistem Solar Tracker dua sumbu, dua rangkaian yang men-tracking cahaya terdiri dari empat sensor LDR yang sama yang diletakkan pada bagian timur, barat, selatan dan utara serta dua motor listrik yang diletakkan pada setiap sumbu (Salem, 2013). Sensor dikonfigurasi dengan cara sensor1 dan sensor2 digunakan untuk men-track matahari secara horizontal sedangkan sensor3 dan sensor4 memungkinkan men-tracking matahari secara vertikal. Untuk mendapatkan panel surya selalu tegak lurus terhadap sinar matahari, diperlukan mencari kesetimbangan antara dua sensor cahaya dimana kedua sensor harus menerima cahaya yang sama sehingga menghasilkan tegangan yang sama. Ketika satu sensor menerima lebih cahaya dari yang lainnya, ini berarti panel surya tidak tegak lurus terhadap sinar matahari dan sebuah tegangan error akan dihasilkan.

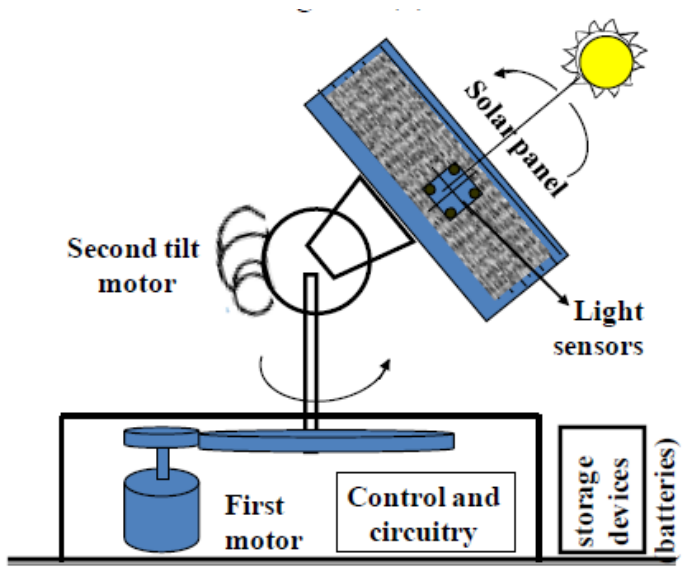

Gambar 4. Solar tracker dua sumbu (Salem, 2013) 
Ketika posisi matahari berubah, intensitas cahaya yang diterima oleh sensor-sensor berbeda, kemudian sistem akan menentukan yang mana sensor menerima intensitas cahaya yang lebih banyak berdasarkan nilai tegangan output sensor yang diterjemahkan oleh konverter tegangan A/D (Analog to Digital). Sistem akan men-drive motor berdasarkan nilai sensor. Jika nilai output dari dua sensor bernilai sama perbedaan output adalah nol dan tegangangan penggerak motor adalah nol yang berarti sistem telah men-track posisi matahari.

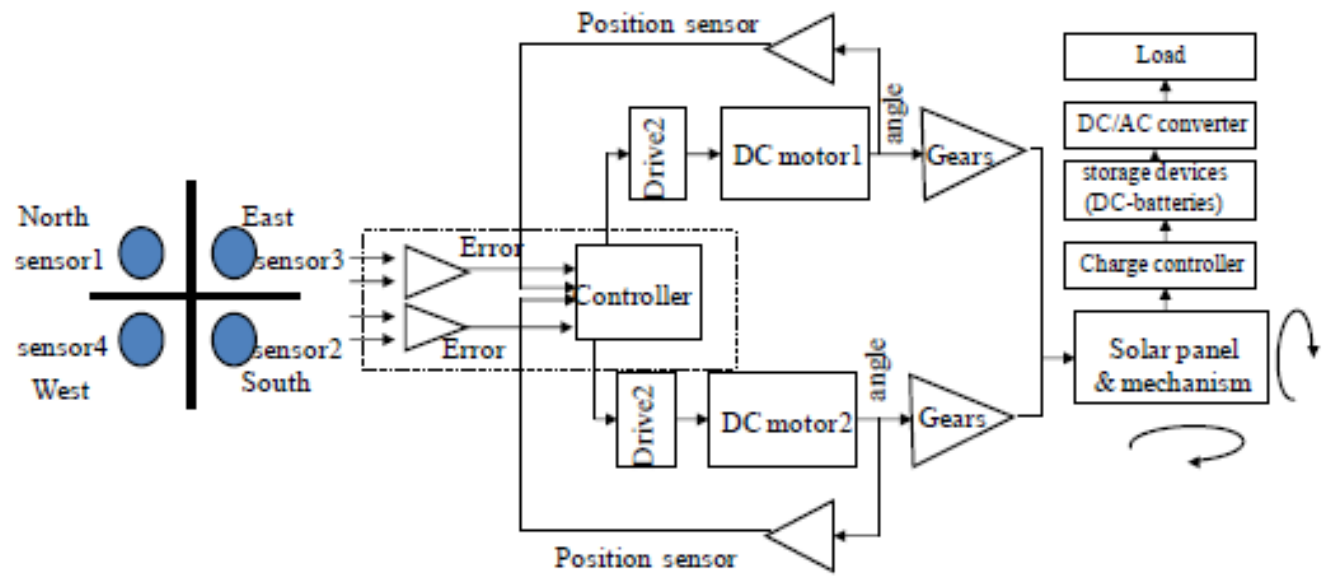

Gambar 5. Susunan sistem solar tracker dua sumbu (Salem, 2013)

\section{METODE}

Alat ukur Volt Meter digunakan untuk mengukur konsumsi daya baterai saat solar tracker beroperasi. Alat ukur ini digunakan saat mengukur efesiensi konsumsi daya yang didapat saat modul sel surya dilengkapi dengan alat solar tracker cerdas dibandingkan dengan yang dilengkapi solar tracker biasa.

Analisis kuantitatif dilakukan untuk menghitung rata-rata efesiensi konsumsi daya yang bisa dihasilkan oleh modul sel surya yang dilengkapi dengan solar tracker cerdas dibandingkan dengan modul sel surya yang dilengkapi solar tracker biasa. Hasil perhitungan ini dapat menggambarkan seberapa besar peningkatan efesiensi konsumsi energi yang dihasilkan oleh modul sel surya yang menggunakan solar tracker cerdas hasil penelitian.

\section{HASIL DAN PEMBAHASAN}

Blok sistem alat solar tracker yang dibuat pada penelitian ini ditunjukkan pada gambar 6 .

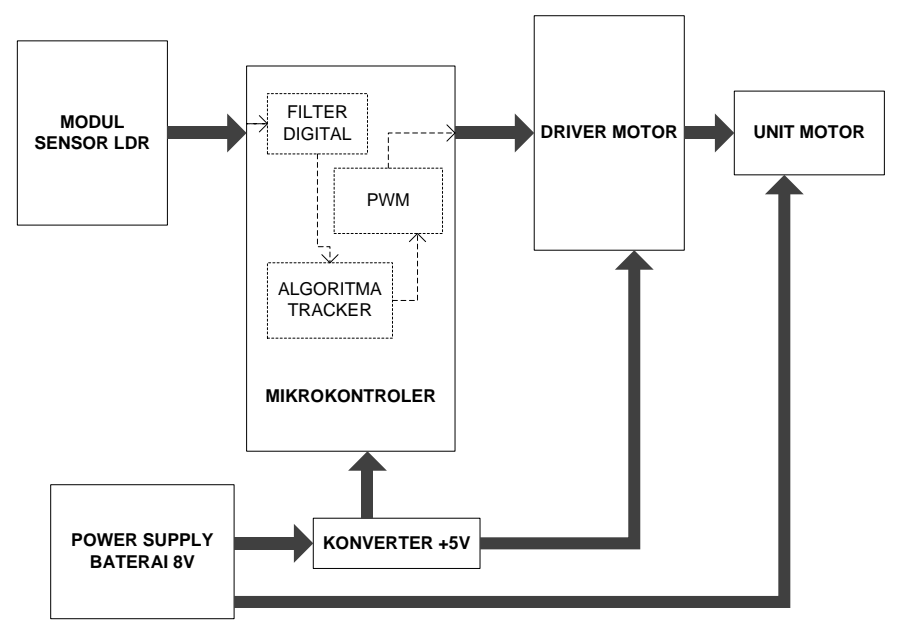

Gambar 6. Blok sistem alat solar tracker 
Penjelasan dari setiap blok pada sistem alat solar tracker sebagai berikut.

\section{Power supply}

Power supply yang digunakan di sini berupa dua buah baterai yang masingmasing $4 \mathrm{~V}$ sebanyak dua buah yang terpasang secara seri. Sehingga total tegangan dari power supply menjadi sebesar $8 \mathrm{~V}$. Alasan mengunakan baterai adalah sebagai media pengujian berapa daya yang habis dari kedua sistem model program yang akan digunakan.

2. Mikrokontroler

Mikrokontroler adalah bagian pengontrol utama dari keseluruhan sistem. Pada mikrokontroler ini akan tertanam program untuk semua proses yang akan dikerjakan oleh alat solar tracker.

3. Konverter

Konverter berfungsi untuk merubah tegangan sumber agar menjadi menjadi $5 \mathrm{~V}$ yang diperlukan oleh mikrokontroler dan unit driver.

\section{Sensor LDR}

Sensor ini sebagai input bagi mikrokontroler. Sensor menghasilkan tegangan dalam bentuk analog. Sehingga mikrokontroler akan mengkonversikannya menjadi digital untuk pengolahan lebih lanjut.

5. Driver Motor

Driver motor digunakan untuk menggerakkan motor. Driver motor ini akan mendapatkan tegangan rendah dari mikrokontroler yang selanjutnya menggerakkan motor sesuai dengan perintah dari mikrokontroler.

6. Unit Motor

Motor sebagai penggerak solar cell yang terpasang padanya. Motor ini akan menggerakkan solar cell ke kanan atau ke kiri sesuai dengan arah datangnya sinar matahari.

Desain hardware secara keseluruhan dari alat solar tracker ditunjukkan pada gambar 7 di bawah. Mikrokontroler digunakan sebagai otak utama dari alat solar tracker yang dibuat. Inputan dari perangkat solar tracker berupa sinyal analog dari sensor cahaya yang terhubung pada port A pin 1 dan port A pin 2. Di sini pin yang digunakan sebanyak dua buah karena sensor yang terhubung juga sebanyak 2 buah. Besar tegangan analog dari sensor yang masuk ini akan dikonversikan menjadi besaran digital dimana mikrokontroler ATMega8535 mempunyai 8 buah pin yang bisa mengkonversikan sinyal analog menjadi sinyal digital. Sedangkan output dari mikrokontroler keluar pada port $\mathrm{C}$ pin 0 dan pin 3. Di sini menggunakan dua pin keluaran agar motor bisa dikendalikan untuk bergerak ke kiri dan ke kanan.

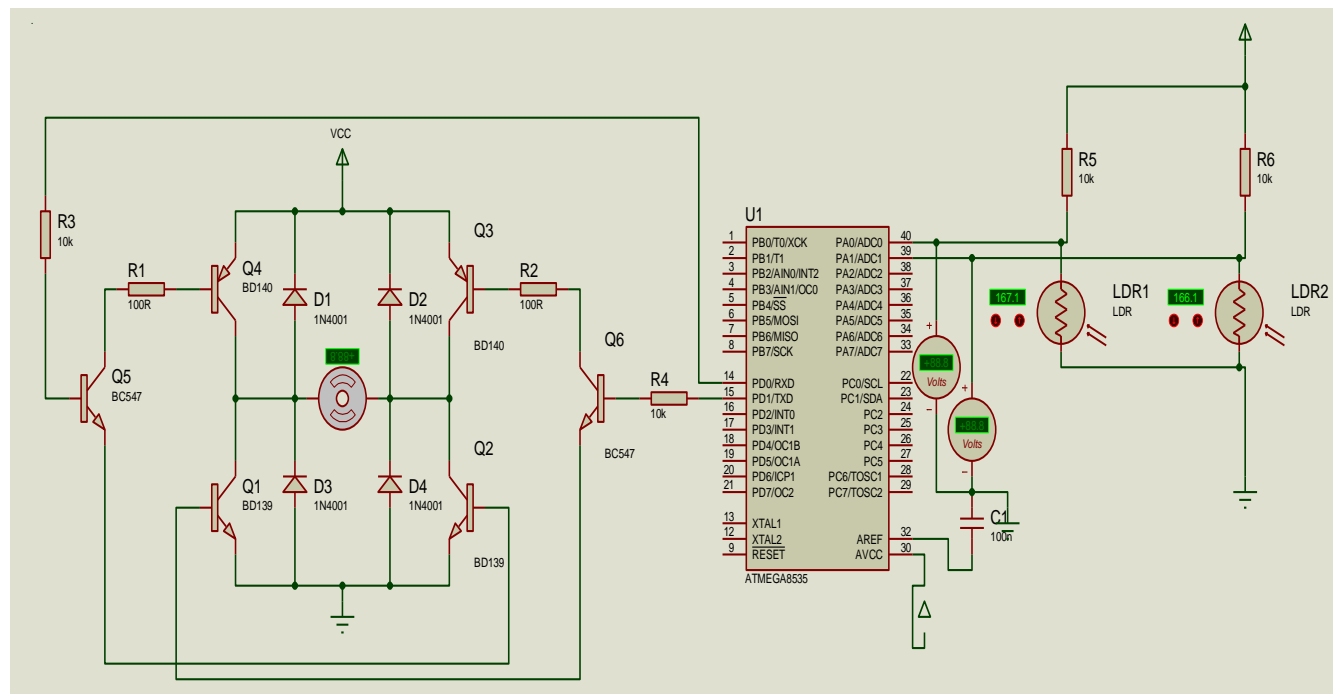

Gambar 7. Desain rangkaian alat solar tracker 
Proses desain rangkaian alat solar tracker yang telah dilakukan menggunakan software proteus. Desain rangkaian dari alat solar tracker di kategorikan menjadi tiga blok dimana penjelasan perblok dari desain hardware ini dijelasakan seperti di bawah.

1. Rangkaian minimum sistem

Rangkaian minimum sistem adalah rangkaian minimum yang diperlukan agar sebuah mikrokontroler (otak dari alat solar tracker) bisa bekerja. Poin utama dalam membuat rangkaian minimum ini adalah ukuran kristal yang digunakan. Ukuran Kristal ini akan menentukan besar clock dari sebuah mikrokontroler. Clock ini berpengaruh pada kecepatan proses dari sebuah mikrokontroler. Pada penelitian ini Kristal yang digunakan berukuran $11.5 \mathrm{MHz}$. Dari sini dapat diketahui besar clock dari mikrokontroler ini adalah $1 / 11.5 \mathrm{MHz}$ atau sama dengan 860 us.

2. Rangkaian driver kendali motor

Rangkaian driver yang didesain di sini berguna untuk mengendalikan motor DC. Rangkaian driver mendapatkan perintah atau input dari mikrokontroler. Apabila pin 0 dari port $C$ yang mengeluarkan tegangan maka motor DC akan bergerak ke kanan. Sedangkan apabila pin 1 dari port $\mathrm{C}$ yang mengeluarkan tegangan maka motor akan bergerak ke kiri. Pada rangkaian ini menggunakan 2 transistor sinyal rendah dan 4 transistor power.

3. Desain rangkaian sensor

Desain rangkaian sensor yang telah dibuat disini berguna sebagai inputan bagi mikrokontroler sehingga mikrokontroler tahu posisi arah datangnya sinar matahari. Di sini terdapat dua rangkaian sensor cahaya. Prinsip kerja dari rangkaian sensor ini adalah seperti rangkaian pembagi tegangan. Sehingga sensor LDR dipasang secara seri dengan resistor. Output dari rangkaian sensor ini diambil pada titik tengah antara resistor dan sensor cahaya. Semakin besar intensitas cahaya yang datang maka nilai tahanan pada sensor akan semakin mengecil sehingga tegangan out menjadi membesar. Begitu pula sebaliknya apabila intensitas cahaya yang datang sedikit maka tahanan sensor akan membesar sehingga menyebabkan tegangan out menjadi mengecil.

\section{A. Algoritma tracker}

Algoritma dari alat solar tracker yang telah dibuat pada penelitian ini ditunjukkan pada gambar 8. Dari gambar tersebut dapat dijelaskan bahwa data yang diberikan oleh dua sensor disimpan pada dua variabel yang berbeda. Selanjutnya data yang disimpan pada variabel-variabel ini ditambahkan dengan 15 kemudian disimpan pada variabel Buffsensor1 dan Buffsensor2. Kegunaan dari variabel-variabel ini adalah untuk memberikan rentang perbedaan sehingga motor tidak diperintahkan terus menerus bergerak pada setiap ada perbedaan nilai tegangan antara dua sensor. Tetapi ditentukan rentang minimal perbedaan yang menyebabkan motor harus bergerak. Selanjutnya terjadi pengecekan apakah tegangan pada sensor1 lebih kecil dari tegangan pada sensor 2. Apabila lebih kecil maka motor DC akan diperintahkan untuk bergerak ke kiri. Motor akan diperintahkan untuk bergerak ke kanan apabila terjadi hal yang sebaliknya. Selanjutnya akan ada proses tunda sebesar 1 detik untuk melakukan proses selanjutnya yaitu mengambil data dari sensor. Hal ini diperlukan karena solar tracker tidak memerlukan pergerakan yang cepat dalam mentrack sinar matahari sehingga bisa mengurangi beban kerja dari perangkat alat solar tracker dengan melakukan proses idling.

\section{B. Algoritma Filter Digital}

Algoritma filter digital yang digunakan pada penelitian ini adalah filter IIR. Filter IIR di sini berupa sebuah firmware dari atmel. Source code dari firmware ini ditulis dalam bahasa assembly. Sehingga memudahkan integrasi program firmware ini kedalam program utama yang dibuat pada penelitian ini. Flow chart dari filter IIR ditunjukkan pada gambar 9 . 


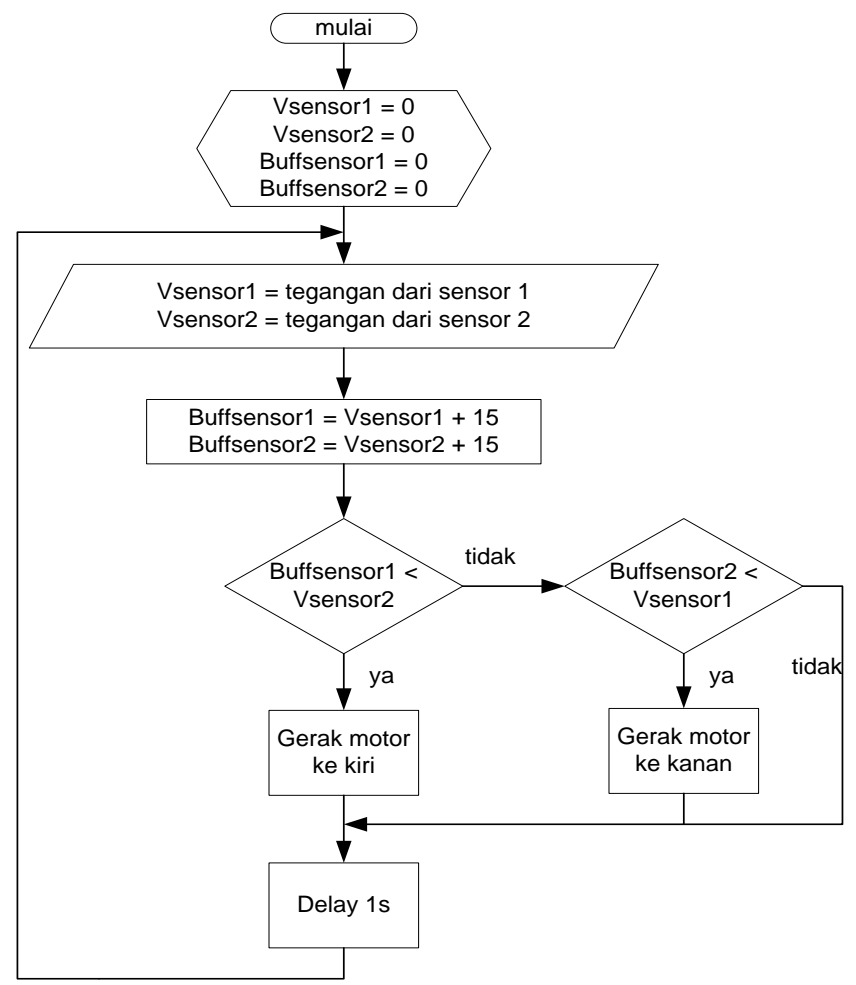

Gambar 8. Algoritma alat solar tracke

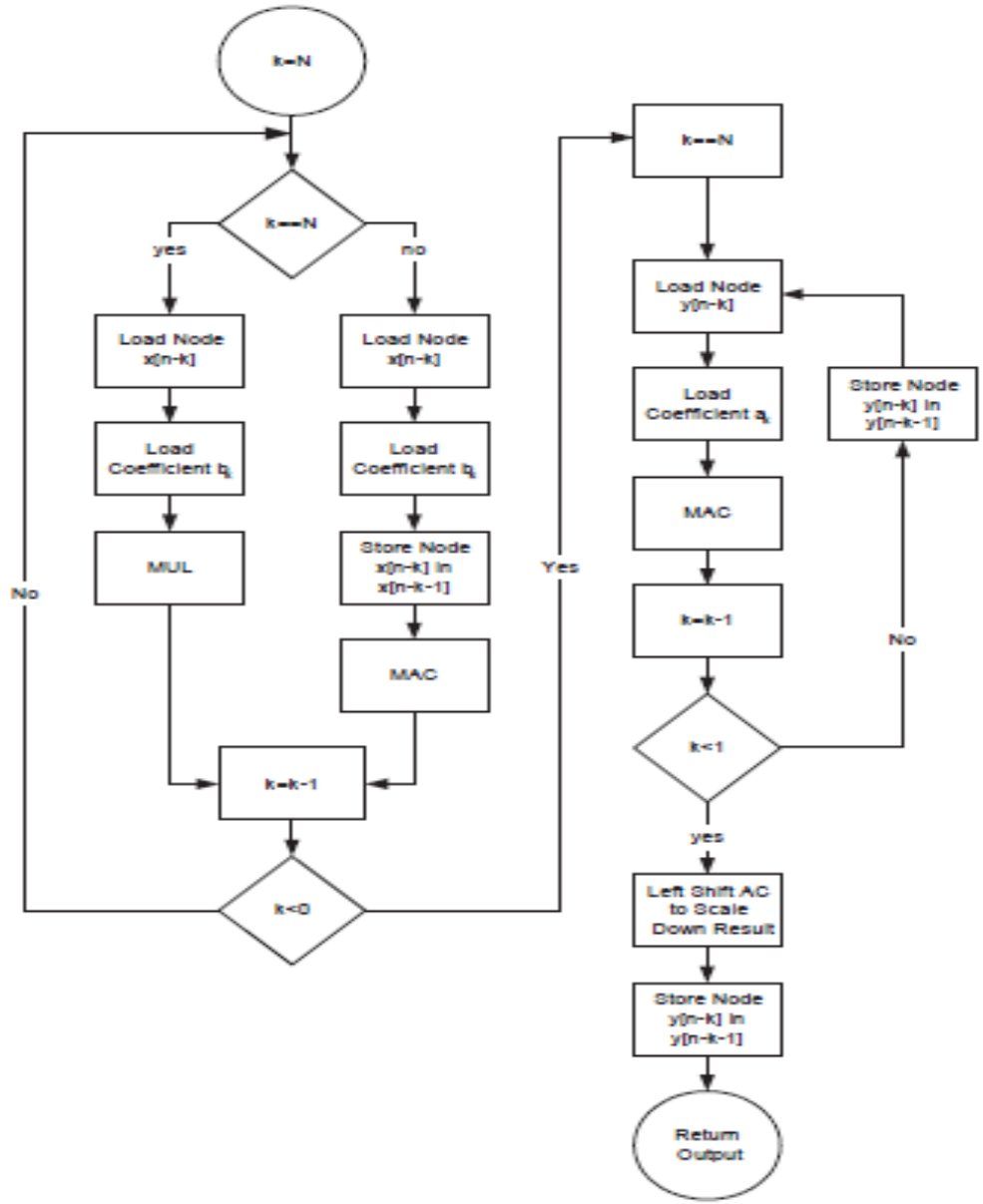

Gambar 9 Flowchart filter IIR (Atmel, 2013) 
Variabel $\mathrm{N}$ menunjukkan jumlah order atau tingkat dari filter. Pada penelitian ini menggunakan filter IIR dua tingkat sehingga nilai $\mathrm{N}$ diseting dua. Tiga data tegangan sensor yaitu saat sedang terjadi pembacaan $x[\mathrm{n}-0]$, data tegangan pembacaan sebelumnya $x[n-1]$ dan tegangan sebelumnya lagi $x[n-2]$. Masingmasing dari ketiga data tegangan sensor ini dikalikan dengan koefesien b0, b1 dan b2. Koefesien sudah ditentukan dari desain pada firmware yang tersedia. Proses sama juga dilakukan pada output. Output dari proses setiap filter untuk setiap tegangan yang dibaca juga disimpan. Selanjutnya output ini dilibatkan kembali dalam proses filter berikutnya. Output dari proses setiap filter disimpan pada y[n-0], y[n-1] dan y[n-2].

$$
y[n]=\sum_{k=0}^{N} b_{k} x[n-k]+\sum_{k=1}^{N} a_{k} y[n-k]
$$

Alat prototipe solar solar tracker yang dihasilkan pada penelitian ini ditunjukkan pada gambar 10. Pengujian secara keseluruhan menunjukkan bahwa alat ini mampu mencari arah datanganya sinar. Ketika rangkaian pada sensor1 mengeluarkan tegangan output sebesar $4.60 \mathrm{~V}$ dan rangkaian pada sensor2 mengeluarkan tegangan sebesar $4.07 \mathrm{~V}$ tidak ada pergerakan pada motor. Hal ini menandakan bahwa motor tidak selalu bergerak setiap ada perbedaan tegangan pada kedua sensor melain harus mencapai perbedaan lebih besar atau sama dengan $59 \mathrm{mV}$. Dari pengamatan secara langsung saat papan solar sel tidak bergerak, posisi papan sudah tegak lurus dengan arah datanganya sinar.

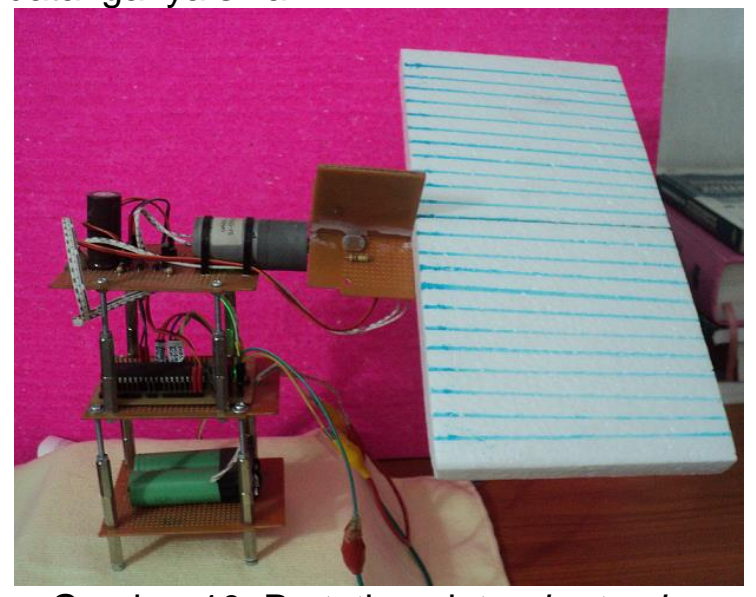

Gambar 10. Prototipe alat solar tracker
Untuk mengukur berapa energi yang dikonsumsi oleh motor DC dalam durasi waktu tertentu maka dihitung dalam watthour. Watthour ini berbanding lurus dengan tegangan baterai seperti yang ditunjukkan pada contoh gambar 11 .

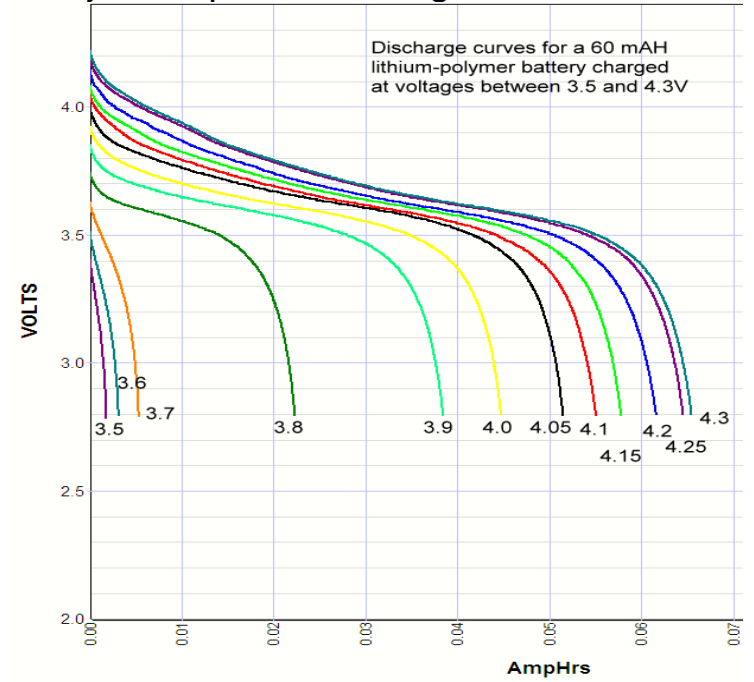

Gambar 11. Grafik pengosongan baterai (Erdinc, 2013)

Dari sini perhitungan penurunan tegangan dapat digunakan sebagai perbandingan dalam membandingkan dua kasus yang diamati. Perbandingan konsumsi daya antara solar tracker cerdas yang dihasilkan pada penelitian ini terhadap solar tracker biasa dengan perlakukan noise yang sama ditunjukkan pada gambar 12.

\section{Perbandingan Konsumsi Daya}



Gambar 12. Perbandingan konsumsi daya antara solar tracker biasa dan solar tracker cerdas

\section{PENUTUP}

Persentase penghematan konsumsi daya pada solar tracker cerdas dengan 
yang tidak cerdas adalah sebesar $85 \%$ pada uji coba penelitian ini. Persentase ini bersifat tidak tetap tergantung banyak noise yang dikenakan. Semakin banyak noise maka persentase semakin besar dan begitu pula sebaliknya. Implementasi filter pada mikrokontroler 8 bit hanya bisa dilakukan dengan bahasa assembly, karena perkalian 32 bit yang digunakan membutuhkan siklus yang banyak. Sehingga diperlukan bahasa assembly untuk memprogram pada level hardware.

Solar tracker cerdas yang dihasilkan pada penelitan ini, perlu diimplementasikan secara nyata di lapangan sehingga akan terlihat kebermanfaatannya. Selai itu, penelitian ini perlu dilanjutkan pada aspek penambahan sumbu putar, sehingga menjadi 2 sumbu serta melihat efek kebermanfaatannya.

\section{DAFTAR PUSTAKA}

Atmel, 2013, Digital Filters with AVR. http://www.atmel.com/images/doc252 7.pdf. (Diakses tanggal: 1 Agustus 2014).

Dhanabar, R., Bharathi V., 2013, Comparison of Efficiencies of Solar Tracker systems with static panel Single-Axis Tracking System and Dual-Axis Tracking System with Fixed Mount, International Journal of Engineering and Technology (IJET), Vol. 5, No. 2, Apr-May 2013, ISSN : 0975-4024.

Erdinc, O., Vural, B., Uzunoglu, M. 2009, A Dynamic Lithium-Ion Batteray Model Considering The Effects of Temparature and Capacity Fading, 2009, IEEE.
Jwo, W., Tong, C., 2010, Firmware Implementation Of An Adaptive Solar Cell Maximum Power Point Tracking Based On PSoC, IEEE.

Mistry, A., Patel, N., 2014, Design of An Automatic Solar Tracking System Based On Microcontroller, International Journal For Technological Research In Engineering, Volume 1, Issue 6, February-2014, ISSN (Online) : 2347 $-4718$.

Ramchandani, V., Kranthi, P., 2013, Implementation of Maximum Power Point Tracking Using Kalman Filter for Solar Photovoltaic Array on FPGA. International Journal of Smart Grid and Clean Energy, Vol. 2, No. 2, May 2013.

Salem, F.A., 2013. Mechatronics Design of Solar Tracking System, International Journal of Current Engineering and Technology, Vol.3, No.3, (August 2013), ISSN 2277 - 4106.

Tudorache, T., Kreindler, L., 2010. Design of a Solar Tracker System for PV Power Plants, Acta Polytechnica Hungarica, Volume 7, Number 1.

Usta, M.A., Akyazi, O., 2011, Design and Performance of Solar Tracking System with Fuzzy Logic Controller, International Advanced Technologies Symposium, 16-18 May 2011.

Zubair, S., Suleiman, A., 2011. Design and Construction of A Microcontroller Based Single Axis Solar Tracker, Journal Innovations in Science and Engineering 1 (2011) 41-4. 